\title{
Computational and experimental characterization of building envelopes based on autoclaved aerated concrete
}

\author{
V. Kočí, J. Výborný \& R. Černý \\ Department of Materials Engineering and Chemistry, \\ Faculty of Civil Engineering, Czech Technical University in Prague, \\ Czech Republic
}

\begin{abstract}
Hygrothermal performances of three types of building envelopes based on autoclaved aerated concrete (AAC) provided with different thermal insulating materials (expanded polystyrene, hydrophilic mineral wool, AAC with extended thermal insulation capability) are compared. The simulations are accomplished using the computer code HEMOT based on the finite element method. Results of the simulation are the moisture and temperature fields across the building envelope, which in combination with mechanical parameters present a sufficient data source for service life analysis.

Keywords: computational analysis, coupled heat and moisture transport, autoclaved aerated concrete, building envelopes, climatic conditions.
\end{abstract}

\section{Introduction}

Autoclaved aerated concrete (AAC) is a structural material which is commonly used around Europe, particularly as it combines ease of construction with excellent combination of its mechanical and thermal properties. However, despite the very good thermal properties of AAC, it can be anticipated that with the increasing demand for energy savings it will become a necessity to provide it with thermal insulating system or at least very good thermal insulating plaster to meet stringent conditions given by future thermal standards. The choice of proper insulating material for AAC is though quite difficult with respect to service life of the whole building envelope. As it was demonstrated in [1-3], most common insulation materials cause extreme hygrothermal straining of 
external finishes so it is necessary to choose wisely. The proper method, how to compare the results is to use computational tool for simulating coupled heat and moisture transport in multi-layered systems of porous building materials. One of such tools which were already successfully tested in previous calculations is HEMOT developed at the Department of Materials Engineering and Chemistry, Faculty of Civil Engineering, Czech Technical University in Prague. This computer code which will be employed in this paper uses Künzel's mathematical model for coupled heat and moisture transport. The equations are solved using finite element method.

\section{Computational analysis}

The computer code HEMOT [4] is based on the general finite element package SIFEL [5]. As basic input parameters of the mathematical model, hygric, thermal and basic physical parameters of used materials, construction detail, initial and boundary conditions and time specification of simulation are required. Description of all input parameters in more detail is given later.

In the computer simulations we focused on a comparison of hygrothermal behavior of several building envelopes based on AAC provided with different thermal insulating materials.

\subsection{Mathematical model}

Künzel's mathematical model of heat and moisture transport [6] was used in the simulations which can be formulated as

$$
\begin{gathered}
\frac{d \rho_{v}}{d \varphi} \frac{\partial \varphi}{\partial t}=\operatorname{div}\left[D_{\varphi} \operatorname{grad} \varphi+\delta_{p} \operatorname{grad}\left(\varphi p_{s}\right)\right] \\
\frac{d H}{d T} \frac{\partial T}{\partial t}=\operatorname{div}(\lambda \operatorname{grad} T)+L_{v} \operatorname{div}\left[\delta_{p} \operatorname{grad}\left(\varphi p_{s}\right)\right]
\end{gathered}
$$

where $\rho_{v}$ is the partial density of moisture, $\varphi$ relative humidity, $\delta_{p}$ permeability of water vapour, $p_{s}$ partial pressure of saturated water vapour, $H$ enthalpy density, $L_{v}$ heat of evaporation of water, $\lambda$ thermal conductivity and $T$ temperature,

$$
D_{\varphi}=D_{w} \frac{d \rho_{v}}{d \varphi}
$$

is liquid moisture diffusivity coefficient, $D_{w}$ capillary transport coefficient.

\subsection{Scheme of construction detail}

Three variations of building envelope based on AAC were chosen for simulation, in order to analyze the consequences of different material combinations. As a 
start-up building envelope we chose AAC without any external finish which allowed us to get real image about hygrothermal performance of AAC layer itself [7]. In the next simulation we provided AAC with hydrophilic mineral wool (marked as Var. 1), expanded polystyrene (Var. 2) and Multipor Ytong produced by Xella CZ (Var. 3). All these envelopes were provided from interior and exterior side with Baumit MVR Uni plaster which is recommended for AAC structures as external finish. On the material interface between mineral wool and AAC an adhesive mortar layer was placed. Description of used materials in more detail is given in next subsection. Scheme of construction detail including the dimensions of each layer is shown in Figure 1. In all investigated variations we focused on the hygrothermal conditions at points within the AAC layer and external plaster just $2 \mathrm{~mm}$ under its external surface which can be considered as characteristic position from the point of view of possible frost damage.

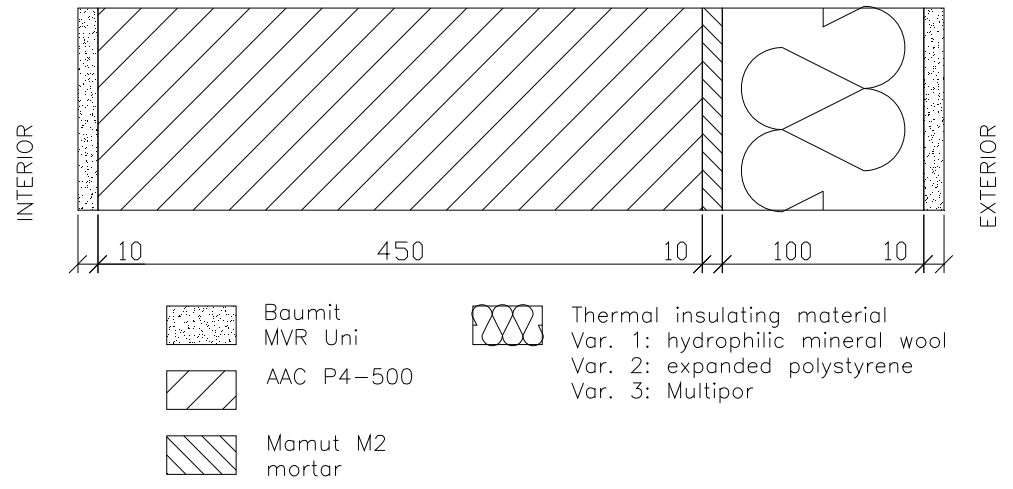

Figure 1: $\quad$ Scheme of AAC-based building envelope.

\subsection{Material parameters}

Aerated autoclaved concrete $\mathrm{P} 4-500$ produced by Xella CZ was under consideration in this paper as the load-bearing material. For exterior and interior renders we used Baumit MVR Uni Plaster, which is single-layer plaster for exterior and interior surfaces especially recommended for AAC. As the thermal insulation we assumed Rockwool hydrophilic mineral wool, expanded polystyrene and Multipor. For adhesive layer between AAC and mineral wool we used Mamut M2 mortar.

All the material parameters were measured in laboratory of transport processes at the Department of Materials Engineering and Chemistry, Faculty of Civil Engineering, Czech Technical University in Prague [8-11] and are summarized in Table 1 and Figure 2. Data for Mamut M2 mortar were measured by M. Jerman and have not been published yet. We used these symbols: $\rho$ - bulk density $\left[\mathrm{kg} / \mathrm{m}^{3}\right], \rho_{\text {mat }}-$ matrix density $\left[\mathrm{kg} / \mathrm{m}^{3}\right], \psi-$ porosity $[\%], c-$ specific heat capacity $[\mathrm{J} / \mathrm{kgK}], \mu$ - water vapour diffusion resistance factor $[-], w-$ moisture content by volume $\left[\mathrm{m}^{3} / \mathrm{m}^{3}\right], \lambda-$ thermal conductivity $[\mathrm{W} / \mathrm{mK}], \kappa-$ moisture diffusivity $\left[\mathrm{m}^{2} / \mathrm{s}\right]$. 
Table 1: $\quad$ Material characteristics.

\begin{tabular}{|c|c|c|c|c|c|c|}
\hline Parameter & $\begin{array}{c}\text { AAC } \\
\text { P4-500 }\end{array}$ & $\begin{array}{c}\text { Mamu } \\
\text { t M2 } \\
\text { mortar }\end{array}$ & $\begin{array}{l}\text { Hydrophi } \\
\text { lic } \\
\text { mineral } \\
\text { wool }\end{array}$ & $\begin{array}{l}\text { Expanded } \\
\text { polystyrene }\end{array}$ & $\begin{array}{l}\text { Multip } \\
\text { or }\end{array}$ & $\begin{array}{c}\text { Baumit } \\
\text { MVR } \\
\text { Uni } \\
\text { plaster }\end{array}$ \\
\hline $\begin{array}{c}\rho \\
{\left[\mathrm{kg} \mathrm{m}^{-3}\right]}\end{array}$ & 500 & 1430 & 71 & 50 & 125 & 1402 \\
\hline$\psi[\%]$ & 80.2 & 42.6 & 96.0 & 97.0 & 94.2 & 44.4 \\
\hline$c\left[\begin{array}{c}\mathrm{J} \mathrm{kg}^{-1} \\
{ }_{1}\end{array}\right.$ & $\begin{array}{c}1020- \\
1510\end{array}$ & 1020 & 810 & 1300 & $\begin{array}{c}2230- \\
3500\end{array}$ & $\begin{array}{c}1020- \\
1780\end{array}$ \\
\hline$\mu[-]$ & $3.0-9.7$ & 12.4 & 4.3 & 50 & $\begin{array}{l}1.9- \\
10.9\end{array}$ & $\begin{array}{l}4.5- \\
12.4\end{array}$ \\
\hline $\begin{array}{c}\lambda_{d r y}\left[\mathrm{~W} \mathrm{~m} \mathrm{~m}^{-1}\right. \\
\left.\mathrm{K}^{-1}\right]\end{array}$ & 0.114 & 0.481 & 0.043 & 0.040 & 0.047 & 0.443 \\
\hline $\begin{array}{c}\lambda_{\text {sat }}\left[\mathrm{W} \mathrm{m}^{-1}\right. \\
\left.\mathrm{K}^{-1}\right]\end{array}$ & 0.454 & 2.022 & 0.246 & 0.560 & 0.166 & 1.380 \\
\hline$\kappa\left[\mathrm{m}^{2} \mathrm{~s}^{-1}\right]$ & Fig. 2 & $\begin{array}{c}1.07 \mathrm{e}- \\
9\end{array}$ & $8.4 \mathrm{e}-6$ & $2.10 \mathrm{e}-11$ & Fig. 2 & $1.59 \mathrm{e}-9$ \\
\hline $\begin{array}{c}w_{h y g} \\
{\left[\mathrm{~m}^{3} \mathrm{~m}^{-3}\right]}\end{array}$ & 0.01846 & 0.201 & 0.000046 & 0.001 & 0.0078 & 0.042 \\
\hline
\end{tabular}

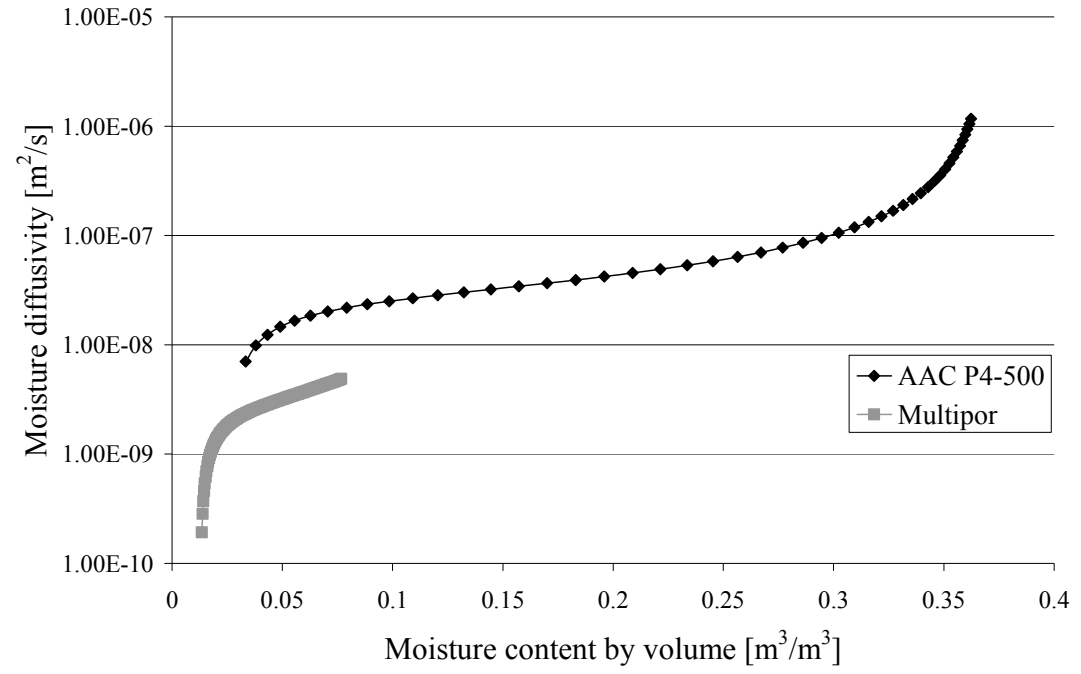

Figure 2: Moisture diffusivity.

\subsection{Initial and boundary conditions and time interval of simulation}

As the initial and boundary conditions climatic data in the exterior in the form of Test Reference Year for Prague which contained average data for 30 years were used. On the interior side constant value of relative humidity $55 \%$ and 
temperature $21^{\circ} \mathrm{C}$ (see Fig. 3) was chosen. The simulation started on $15^{\text {th }}$ July and took 6 years. The final results show data obtained for the last year.

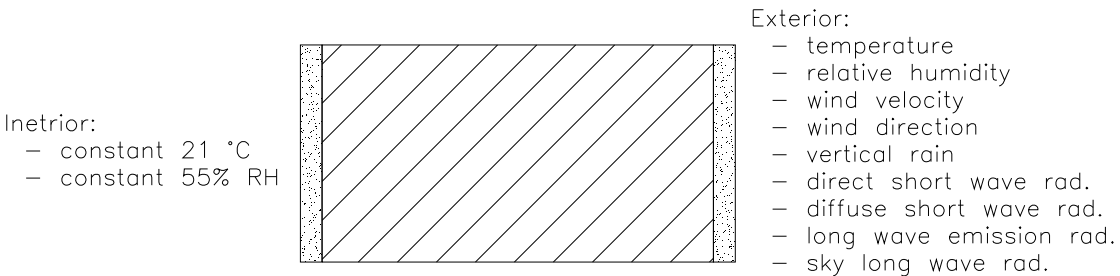

Figure 3: $\quad$ Boundary conditions.

\section{Computational results}

The results of computational simulations are summarized in a set of figures which describe hygric and thermal performance of studied material of building envelope during a reference year. In all figures we focused on moments when moisture content and temperature reached certain limits simultaneously. In case of moisture content this limit was the value of hygroscopic moisture content (see Tab. 1), in case of temperature the freezing point of water. When these two conditions are fulfilled, contained liquid moisture is getting frozen. This leads to consequent damage of material.

The materials capability to resist to freezing of contained water is characterized by its freeze-thaw resistance which can be measured under laboratory conditions [12]. This was accomplished for AAC and its freeze-thaw resistance was set to 25 cycles [13]. Durability of AAC can be then calculated as quotient of freeze-thaw resistance and number of freezing cycles appearing in the material in building envelope during a year.

\subsection{AAC wall provided with hydrophilic mineral wool}

Hygrothermal performance of AAC and external plaster of building envelope provided with hydrophilic mineral wool is captured in Figures 4 and 5.

The temperature in AAC block $2 \mathrm{~mm}$ under its external surface is lower than in other investigated envelopes, but freezing point of water is not reached and level of moisture content is deeply in underhygroscopic range. That means that AAC block in not threatened by effects of freezing water.

Hygrothermal performance of exterior plaster is shown in Figure 5. Although the temperature drops below zero many times during a reference year, this does not happen simultaneously with moisture increase. So, there is not any water which can freeze and damage the structure of plaster. During a reference year, the overhygroscopic moisture content is reached only five times and only in summer months. So we can summarize, that even in the plaster there are not any freezing cycles. 


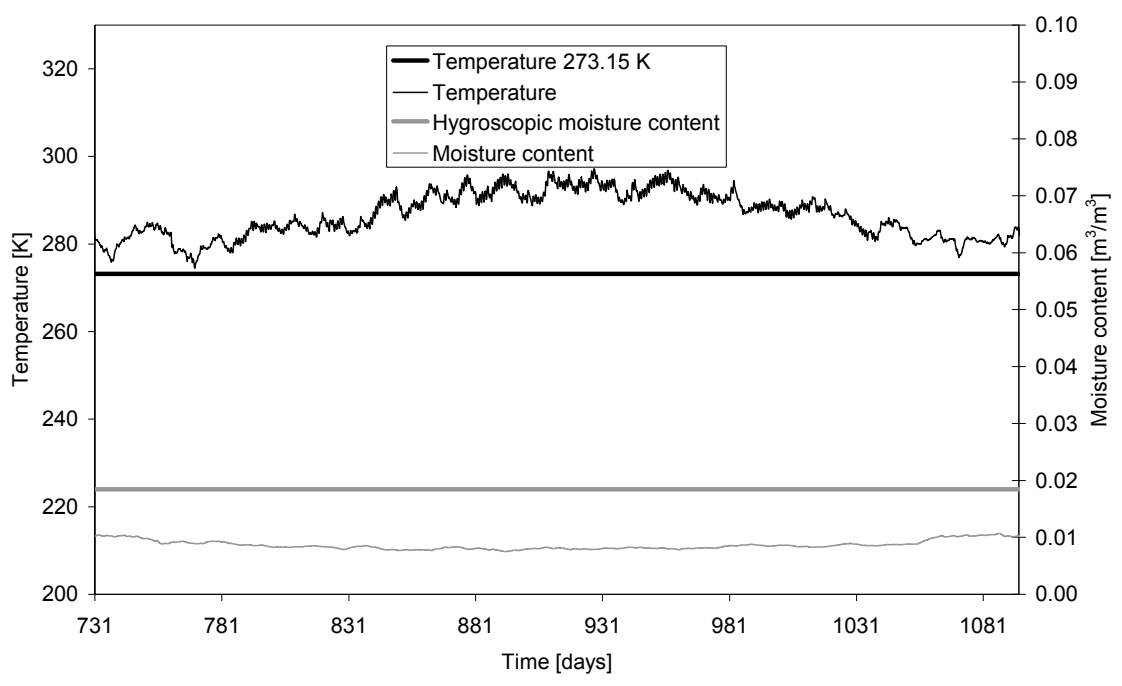

Figure 4: Hygrothermal performance of AAC, Var. 1.

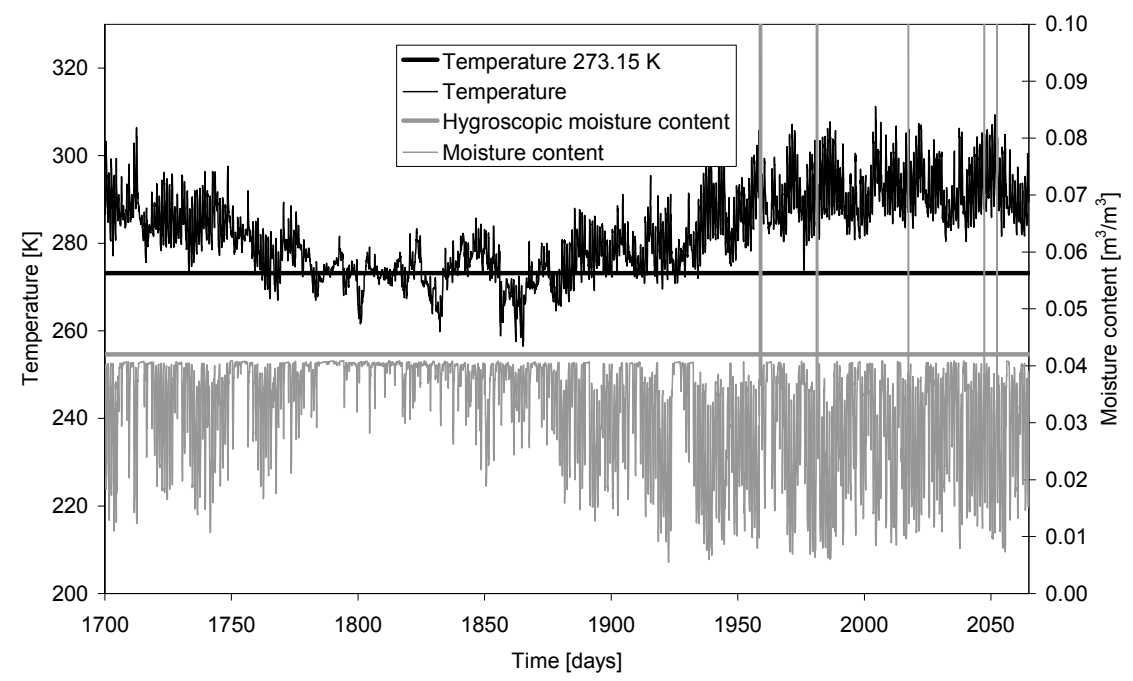

Figure 5: Hygrothermal performance of exterior plaster, Var. 1.

\subsection{AAC wall provided with expanded polystyrene}

The results of hygrothermal performance of AAC wall provided with expanded polystyrene are shown in Figures 6 and 7.

In $\mathrm{AAC}$, the values of temperatures keep above $0^{\circ} \mathrm{C}$ for all the year, the level of moisture content stays in underhygroscopic range. It means that any single condition for creation of freezing cycle is not fulfilled. 


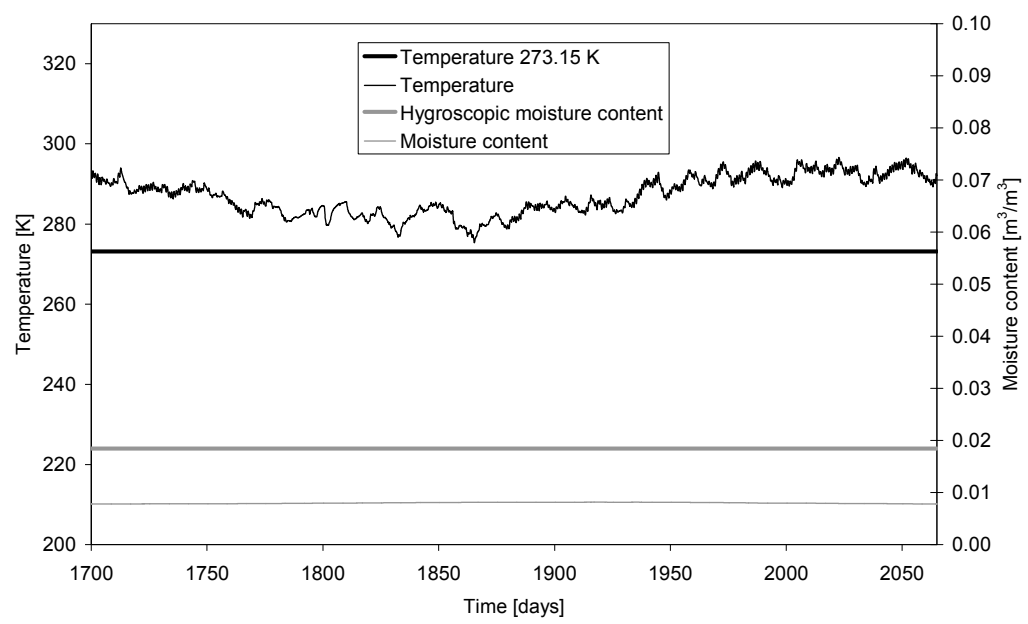

Figure 6: Hygrothermal performance of AAC, Var. 2.

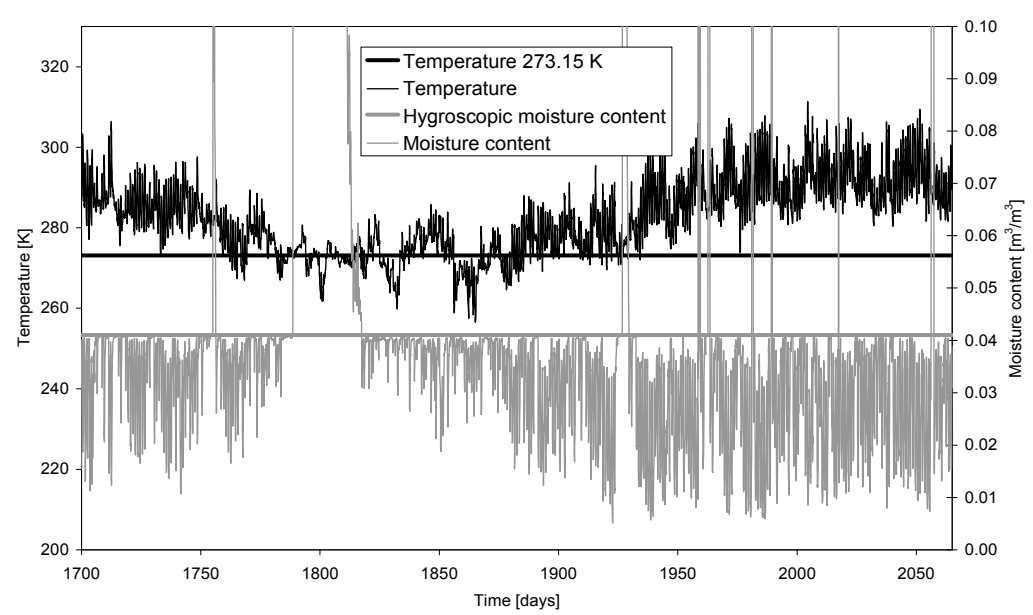

Figure 7: Hygrothermal performance of exterior plaster, Var. 2.

A different situation appears in exterior plaster as one can see in Figure 7. There are few moments, when the level of moisture content reaches overhygroscopic range for sufficiently long time. The most interesting moments are these in winter, when the temperature drops below zero (around $1800^{\text {th }}$ day of simulation). In hygrothermal simulation of this type of building envelope, 15 freezing cycles per a year are counted in exterior plaster.

\subsection{AAC wall provided with Multipor}

Figures 8 and 9 capture hygrothermal performance of AAC and exterior plaster of wall provided with Multipor. 
As in the previous variations, the hygrothermal performance of AAC is similar. There are not any freezing cycles because of relatively high temperature and low moisture content (see Figure 8).

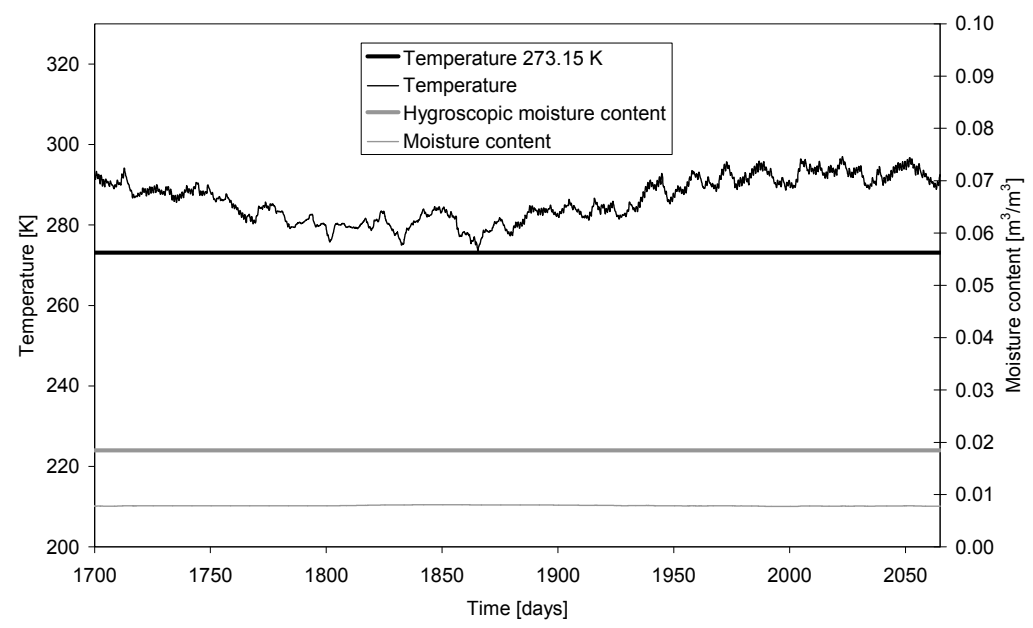

Figure 8: Hygrothermal performance of AAC, Var. 3.

In exterior plaster applied on Multipor insulation, 10 freezing cycles are counted (see Fig. 9). Between $1789^{\text {th }}$ and $1814^{\text {th }}$ day of simulation the moisture is in overhygroscopic range and at the same time the temperature drops below zero so the condition for creation of freezing cycles is fulfilled.

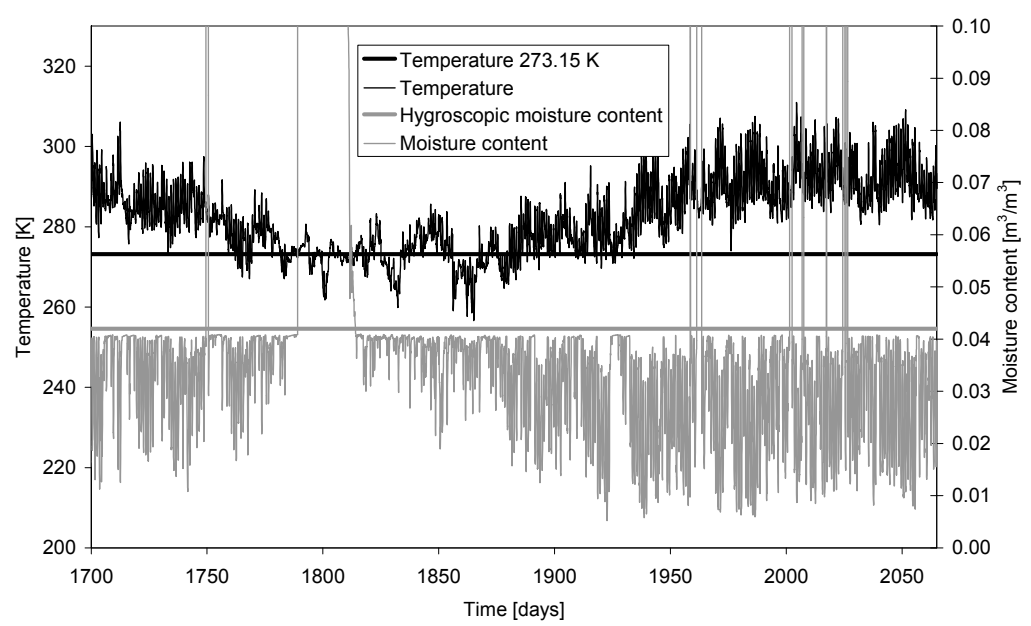

Figure 9: Hygrothermal performance of exterior plaster, Var. 3. 


\section{Discussion}

The protection of AAC walls against effects of weather conditions and freezing water in particular is certainly a necessity. It was proved already in the previous work [7]. There are two ways how to achieve that. The AAC wall can be protected against increase of moisture content which can be accomplished by suitable waterproof modification of external surface or we can protect the wall against low temperatures using one of many thermal insulating materials. The second possibility seems to be more advantageous with respect to stringent conditions given by thermal standards which have to be met.

The advantage of thermal insulation applied on AAC is the fact that together with frost the AAC is protected against moisture penetrating from exterior as well. However, the application of thermal insulation goes along with negative effects. One of the most significant is extreme straining of external finishes, which are applied on. This was already indicated in [1-3] and also results obtained in this paper confirmed it.

The main reason can be seen in the low moisture diffusivity of used thermal insulating materials (expanded polystyrene, Multipor). This leads to slowing down the moisture transport from exterior plaster towards the interior and to moisture increase in plaster subsequently. Considering the direct exposition of plaster to weather conditions, temperature in particular, water saturated plaster can be then easily damaged by effects of freezing of contained liquid moisture. It can be spoken in general, the lower moisture diffusivity of thermal insulating material is, the more freezing cycles in exterior plaster will appear. In our case, there were 15 freezing cycles in plaster applied on expanded polystyrene and 10 freezing cycles in plaster applied on Multipor and that corresponds to values of moisture diffusivity.

Opposite situation occurred when hydrophilic mineral wool has been used. Thanks to high moisture diffusivity of hydrophilic mineral wool, all the received moisture can be quickly transported away, so the plaster stays relatively dry and does not contain the liquid moisture. On the other hand, moisture content of AAC is higher, which is obvious, when Figures 4, 6 and 8 are compared.

Although the moisture content is still very low, the total amount of moisture contained in whole building envelope provided with hydrophilic mineral wool is higher than in other studied cases so that the thermal insulating capability of that building envelope may possibly decrease.

\section{Conclusion}

According to the results obtained in this paper, protection of AAC block in building envelopes against weather conditions is a necessity. It can be accomplished in many ways; one of the best seems to be using thermal insulating materials from exterior side. In this paper, computational simulation of building envelopes provided with different types of thermal insulating materials has been accomplished. The best results were obtained when hydrophilic mineral wool was under consideration. The other variants with expanded polystyrene or 
thermally insulation AAC material Multipor did not lead to suitable results. It was caused by low value of moisture diffusivity which was the cause of increase of moisture content in exterior plaster. The level of moisture content then exceeded the hygroscopic limit and freezing of liquid water was allowed.

The building envelope with hydrophilic mineral wool showed different hygrothermal performance. High value of moisture diffusivity of mineral wool allowed water to be transported deeper into the envelope which led to decrease of moisture content in external plaster. Protection against effects of freezing water was sufficiently fulfilled. However, total moisture content in building envelope was then higher.

In next research, it would be advisable to focus on design of new insulating materials or modification of material parameters of current materials using inverse analysis in order to find the composition of AAC-based building envelope which will combine good frost resistance and good thermal insulating properties as well.

\section{Acknowledgement}

This research has been supported by the Czech Science Foundation, under grant No. 103/09/0016.

\section{References}

[1] Maděra, J., Kočí, V., Vejmelková, E., Černý, R., Rovnaníková, P. et al, Influence of material characteristics of concrete and thermal insulation on the service life of exterior renders. In: Fourteenth International Conference on Computational Methods and Experimental Measurements, Algarve, Portugal. Wessex: WIT PRESS, p. 13-23. ISBN 978-1-84564-187-0. 2009.

[2] Maděra, J., Kočí, V., Korecký, T., Černý, R. et al. Computational analysis of hygrothermal performance of building envelope under different climatic conditions In: Thermophysics 2010. Brno: University of Technology, p. 180-187. ISBN 978-80-214-4166-8. 2010.

[3] Jerman, M., Kočí, V., Maděra, J., Výborný, J., Černý, R, Water and heat transport parameters of materials involved in AAC-based building envelopes In: 1st Central European Symposium on Building Physics. Lodz: Technical University of Lodz, p. 39-45. ISBN 978-83-7283-367-9. 2010.

[4] Černý R., Complex System of Methods for Directed Design and Assessment of Functional Properties of Building Materials: Assessment and Synthesis of Analytical Data and Construction of the System. CTN CTU in Prague, 192 - 201. 2010.

[5] Kruis, J., Koudelka, T., Krejčí, T., Efficient computer implementation of coupled hydro-thermo-mechanical analysis. In: Mathematics and Computers in Simulations, vol. 80, no. 8, pp. 1578-1588. ISSN 0378-4754. 2010.

[6] Künzel, H.M., Simultaneous Heat and Moisture Transport in Building Components, Ph.D. Thesis, IRB Verlag: Stuttgart, pp. 1-135, 1995. 
[7] Maděra, J., Kočí, J., Kočí, V., Výborný, J., Černý, R., Computational prediction of hygrothermal conditions in innovated AAC-based building envelopes. In: Advanced Computational Methods and Experiments in Heat Transfer XI. Southampton: WIT Press, pp. 291-301. ISBN 978-1-84564462-8. 2010.

[8] Jiřičková, M. and Černý, R., Effect of Hydrophilic Admixtures on Moisture and Heat Transport and Storage Parameters of Mineral Wool, Construction and Building Materials, 20, 425-434, 2006.

[9] Výborný, J. Stanovení tepelných parametrů a smrštění při vysychání vybraných pórobetonových tvárnic firmy $\mathrm{H}+\mathrm{H}$ Česká republika s.r.o. a Xella CZ. In: Proceedings of the International Conference 15th Construmat 2009. Praha: České vysoké učení technické v Praze, pp. 449-461. 2009.

[10] Fučíková, L., Moisture Properties of AAC Blocks in dependence on the Environment Focused on Problems with Durability. Diploma thesis. Praha: Czech Technical University in Prague, 2009.

[11] Jerman, M., Výborný, J., Černý, R., Tepelné a vlhkostní charakteristiky nových pórobetonových výrobků, In: Stavebni obzor, roč. 20, č. 1, s. 7-11. ISSN 1210-4027. 2010.

[12] ČSN EN 15304. Determination of the freeze - thaw resistance of autoclaved aerated concrete. Praha: Czech Standards Institute, 2007.

[13] Výborný, J., Testing of the Drying Shrinkage and Freeze - thaw Resistance of Autoclaved Aerated Concrete. In: XII International scientific conference Technická zařizení staveb a energie budov. Brno: Akademické nakladatelství CERM, pp. 215-218. 2009. 